\title{
TECHNOLOGY OF CREATING AND USAGE OF PROECOLOGICAL BLOCK EMPTYSEED
}

\section{TECHNOLOGIA WYTWORZENIA I ZASTOSOWANIA EKOLOGICZNEGO PUSTAKA EMPTYSEED W ARCHITEKTURZE}

\author{
Jan Cudzik \\ dr inż. arch. \\ Author's Orcid number: 0000-0002-8162-2447 \\ Konstancja Olszewska \\ mgr inż. arch. \\ Author's Orcid number: 0000-0003-4110-1871 \\ Politechnika Gdańska \\ Wydział Architektury \\ Katedra Architektury Miejskiej I Przestrzeni Nadwodnych
}

\begin{abstract}
Nowadays, finding natural substitutes for mass-produced materials is one of the main tasks faced by scientists and designers. There is an increasing emphasis on the theme of ecology and the need for sustainability. Variants and methods are sought which will create environmentally friendly materials in a fast, relatively inexpensive and ecological way. The aim of this paper is to present different proposals of natural building materials and to demonstrate the research process in the search for an environmentally friendly facade material, analyzing it in terms of strength, durability and aesthetics. One of the reasons for this is the steadily deteriorating environmental conditions. Thus, architects strive to improve environmental safety.
\end{abstract}

Key words: architecture, eco-materials, ecology, facade block, sustainable development.

\section{STRESZCZENIE}

Współcześnie odnalezienie naturalnych zamienników dla masowo wykorzystywanych materiałów jest jednym z podstawowych zadań stawianych przed naukowcami i projektantami. Coraz częściej kładzie się nacisk na tematykę ekologii i potrzebę zrównoważonego rozwoju. Szukane są warianty oraz metody, które w szybki, względnie tani i ekologiczny sposób stworzą materiały przyjazne dla środowiska. Celem artykułu jest przedstawienie różnych propozycji naturalnych budulców i wykazanie procesu badań w poszukiwaniu przyjaznego dla środowiska materiału elewacyjnego, analizując go pod kątem wytrzymałości, trwałości oraz estetyki. Jedynym z powodów tych działań są stale pogarszające się warunki środowiskowe; z tej przyczyny architekci starają się wpłynąć na poprawę bezpieczeństwa ekologicznego.

Słowa kluczowe: architektura, eco-materiały, ekologia, pustak elewacyjny, zrównoważony rozwój. 


\section{INTRODUCTION}

Nowadays architects and designers constantly look for natural, ecological substitutes for mass-produced elements, which contribute to environmental pollution. The issue is being addressed not only by biologists and scientists, but also by an increasingly informed society concerned about the future of the planet. The need for sustainability is a major aim for designers and architects who want to put their ideals into practice and thus fit their projects into high eco-standards. For this reason, there is a constant emphasis not only on the visual aspects of the buildings, but also on the environmental aspects and integration with nature.

The problem has been already examined on various levels. One of contemporary approaches is analysed by Magdalena Zych in her publication entitled Architecture of educational buildings with an ecological certicicate. The paper puts emphasis on ecological solutions in terms of form, function and used materials. Zych argues: Constantly deteriorating condition of the natural environment directly affects the need for widespread use of ecological solutions. The concept of pro-ecological architecture should embrace not only housing but also public facilities, including educational buildings (Zych M., 2020). Moreover, in the work Selection criteria of thermo-insulating materials to insulate wooden building facilities the authors focused on the same issue, but this time the research was limited to two natural materials: wood wool and glass wool in terms of insulating properties (Misztal B., Mielińska A., 2021). The authors explore how changes in moisture levels affect the structure of the building. Furthermore, Piotr Wróbel refers to the interaction between architecture and nature in the era of climate change. He attempts to estimate how weather changes affect built structures and proposes the implementation of a radical concept to eliminate activities that are incompatible with the green architecture formula (Wróbel P., 2019).

In order to introduce sustainable and safe development construction and maintenance of structures, a law was created in Poland - Construction Law (in Polish: Ustawa o Prawie budowlanym (Ustawa 1994). The act regulates environmental issues during all stages of construction, including action in the event of a construction or demolition disaster. Similarly, the Act on Construction Products (in Polish: Ustawa 2004). addresses similar issues, this time focusing on the products themselves, their properties and the degree of use. In addition, it controls finished products placed on the market and their impact on the surrounding nature. However, these regulations are not considered special acts because they do not contain all the relevant standards for ecologists.

The enormous scale of the problem associated with the fight against excess waste and polluted environment can be seen from a legal point of view. For the last few years, there has been a dispute about whether the right to ecology should be treated as one of the fundamental human rights and freedoms. In view of the influence exerted by the need for access to a cleaner environment, to the associated health, to natural substitutes for plastics, the majority are supporters of this perspective, who believe that the content, character, as well as the very sense of the law in question is already undeniable. Moreover, it is so extensive (it concerns practically everyone) that it should be available, universal and directly enforced, having normative basis. This has been a subject to series of research issues. Piotr Korzeniowski draws attention to the disintegration of Polish legal acts, which numerous amendments to the environmental law adversely affected the level of maintenance of ecological safety. The confirms emphasize that the seemingly developed system does not meet the standards of the European Union and has separate features from other branches of law (Korzeniowski P., 2012). This may be connected with the increasing chaos in the sphere of taking care of the environment.

\section{METHODS}

Nowadays, the meaning of biodegradable materials seems to be a relevant topic. Architects try to find more and more interesting and durable forms, thanks to which they can achieve similar or even the same effects as in mass production. There are also ecological motives behind these ideas, such as fighting excessive waste, segregating trash, reducing carbon emissions, cleaning up water or fighting plastic pollution. The latter seems to be the scourge of the XXI century, and it is no wonder that ecological alternatives are being sought for plastic, mainly as a building material in architecture 
and everyday use items. Przemysław Brzyski refers to this problem noting that construction in the 21 st century is the reason and generator of a huge amount of waste and stresses that for plastics which are difficult to recycle, natural substitutes are constantly being sought, mainly those of plant origin (Brzyski P., 2016).

One of the ecological solutions is Hempcrete, a brick made from hemp and lime, is gaining in popularity. It is an ideal material for both insulation and construction, because it contains cellulose, so unlike man-made chemical fibers it does not irritate either the respiratory tract or human skin. Builders use this strong yet lightweight material to construct entire housing estates. Hempcrete is extremely resistant to pests, and what is more, it is fire resistant and renewable. Barbara Pietruszka and Michał Gołębiewski emphasize not only the ecological, but also the thermal-moisture and biological values of hemp as a building material. They point out that an increase in the popularity of this material in Poland takes time due to underdeveloped cultivation areas and the need for technological facilities (Pietruszka B., Gołębiewski M. 2019). The acoustic and thermal insulation and thermal mass of hempcrete have also been appreciated by William Stanwix and Alex Sparrow who describe the whole process of using this natural ingredient and also focus on the positive aspects of its use. They stress, among other things, that there is no need to use artificial fertilizers or agrochemicals when growing hemp (Stanwix W., Sparrow A., 2014).

Another natural building material used by architects (mainly in Asia, Africa and Latin America) is bamboo who appreciated its high strength with the lightness of material. The straight, hollow stem is used, and bamboo meal commonly replaces basic materials such as wood or concrete in the construction of doors, floors and roof structures. Kitti Chaowana and other authors stress the properties of bamboo as a relatively environmentally friendly building material and a sustainable building product. Studies focused on the characteristics of this material have shown that in physical and mechanical terms, bamboo shows increased strength compared to other similar fibers. From an architectural and engineering perspective, bamboo is considered as a material with properties similar to other natural building blocks (Chaowana K., Wisadsatorn S., Chaowana P., 2021)

The positive aspects of the plants are appreciated by producers as well as coffee gourmets - more and more initiatives are being created with coffee grounds waste. Many authors claim that several plant-based materials are nowadays used in packaging and biofuel production (...) coffee waste can be considered as a valuable source in recycling strategies for the sustainable production of bio-based chemicals, materials and fuels. What is more, they notice that searching for sustainable alternatives to petroleum feedstocks is also becoming increasingly interesting in the extraction of fuels from biosources. Coffee waste is an inexpensive raw material containing fatty acids that can be used as a sustainable carbon source and is also an interesting source of bioactive compounds and fibres (Sisti L. et al., 2021). This solution was used by a Polish company EcoBean for the production of briquette from coffee grounds. Originators believe that it is definitely more ecological version in comparison to wood briquette. The production is based on the fact that the grounds are first dried and cleaned, then combined with combustion materials and finally compressed. Coffee grounds briquette emits more energy than wood briquette. By doing so, the company hopes to reduce co2 emissions and the resulting pollution. Additionally, EcoBean has plans to build a zero-emission and zero-waste factory to process coffee grounds.

Biodegradable, natural ingredients are the first step in the fight for a better tomorrow and sustainability. In this battle, it will be essential to expand the terrain of green construction, as Defne Hensel repeatedly emphasises. He has addressed such an important issue as ecological prototypes, involving the creation of integrated and adaptive systems of both design and construction and practices. They all combine ecology, landscape, as well as architecture, agriculture and horticulture. The modern GC system was designed to balance environmental goals and social needs, including influencing the revitalization of commercial areas. The aim of these activities is not only to provide ecosystem services, but also to revitalize degraded peripheral urban fringes. (Hensel D.S. , 2020) 


\section{THE PROJECT OF ECOLOGICAL BLOCK EMPTYSEED}

\subsection{Idea}

The main concept of the project was an attempt to create a material from renewable raw materials in such a way as to create an environmentally friendly and at the same time architecturally innovative work. Aesthetic qualities also played their part, as the blocks were a decorative element of the building's façade(Fig. 1). Working with the ideal form and the properties of natural ingredients, the experiments resulted in a durable, long-lasting block that is fully biodegradable.
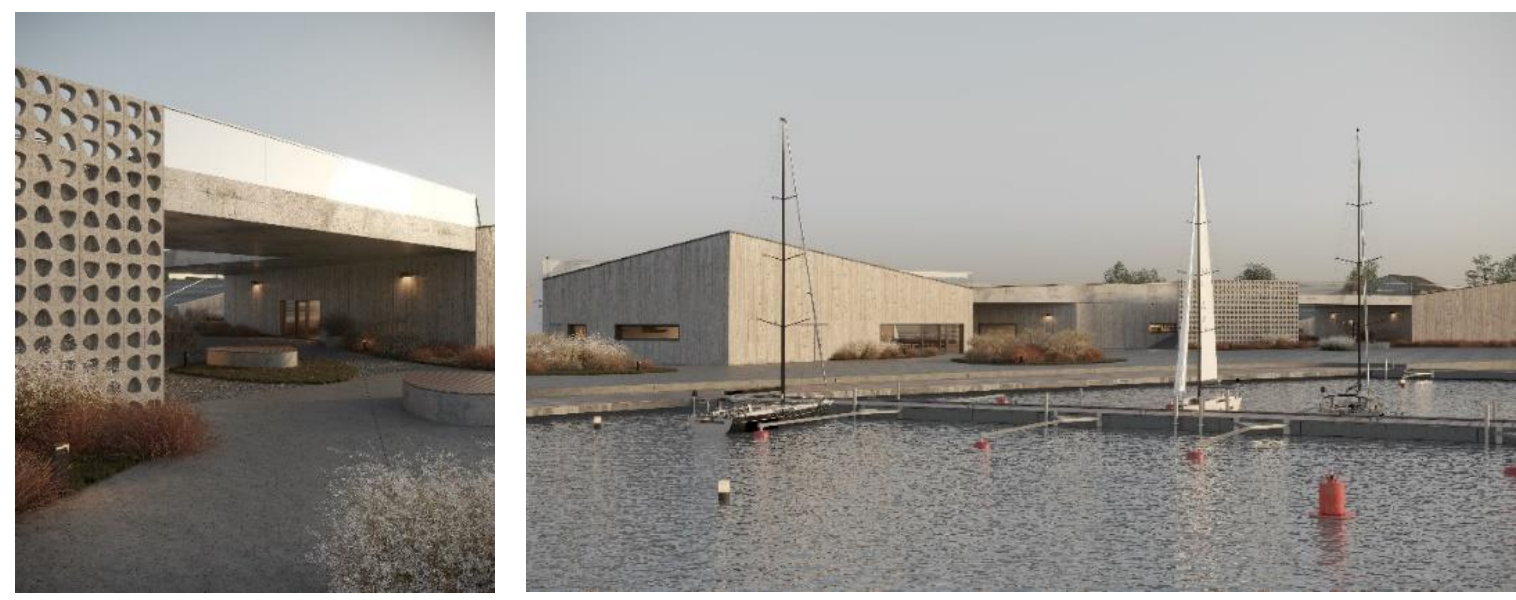

Fig. 1. Walls using blocks Emptyseed - visualizations. Source: Authors' materials

Rys. 1. Ścianki z wykorzystaniem pustaków Emptyseed - wizualizacje. Źródło: Opracowanie własne

\subsection{Form}

The ecological block Emptyseed has a simple, minimalist form with dimensions: height $40 \mathrm{~cm}$, width $40 \mathrm{~cm}$ and thickness $20 \mathrm{~cm}$. The lump is based on a square with a hole in the middle. The opening refers to the elements of small architecture in the aforementioned master's project about the marina. The Emptyseed was designed as to make work easier, not only for construction workers, but also for outsiders who can make their own hollow blocks in the future. For this reason, no more components were needed to create Emptyseed than with mass-produced products.
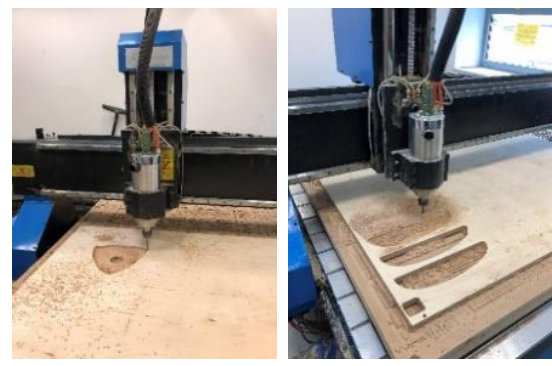

Fig. 2. Cutting out parts using CNC milling machine. Source: Authors' materials

Ryc. 2. Wycinanie elementów za pomocą frezarki CNC. Źródło: Opracowanie własne
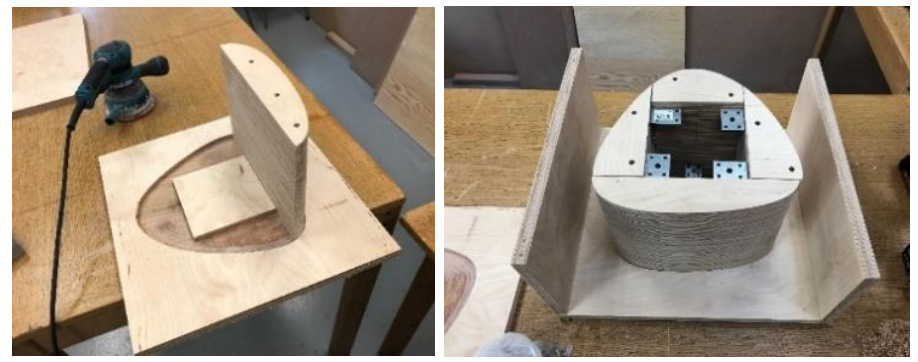

Fig. 3. Combining elements to make the mold. Source: Authors' materials Ryc. 3. Łączenie elementów na formę. Źródło: Opracowanie własne

The first step was to enter the data into AutoCad and 3dsMax. The second was to determine the dimensions of the block in such a way that the solid could be created and took a specific shape. 
Then the obtained information was generated in Rhino software to prepare the file for fabrication. Next, the elements were cut out of the waterproof leafy plywood with a size of $250 \times 125 \mathrm{~cm}$ with a thickness of $8 \mathrm{~mm}$ using the CNC milling machine (Fig. 2). The resulting pieces had to be sanded with a wood sander and sandpaper. The final mold for the block consisted of 49 pieces, which were joined together using angle brackets and screws (Fig. 3).

Tab.1. Collation of material samples (for strength and structure) Source: Authors' materials Tab.1. Zestawienie próbek materiału (pod kątem wytrzymałości i struktury) Źródło: Opracowanie własne

\begin{tabular}{|c|c|c|c|}
\hline No./ $\mathrm{Nr}$ & Proportion of materials / Proporcje materiałów & Mark / Ocena & Photographs / Zdjęcia \\
\hline 1 & $\begin{array}{l}\text { cement - sand - seeds - microfibres - water } \\
\text { cement - piasek - nasiona - mikrowłókna - woda } \\
\left.\text { (ratio/stosunek: } 3 \frac{1}{2}: 1 \frac{1}{2}: 1: 1: 4\right)\end{array}$ & 10.0 & \\
\hline 2 & $\begin{array}{l}\text { cement - sand - seeds - microfibres - water } \\
\text { cement - piasek - nasiona - mikrowłókna - woda } \\
\text { (ratio/stosunek: } 3 \frac{1}{2}: 1 \frac{1}{2}: 1: \frac{1}{2}: 3 \text { ) }\end{array}$ & 9.00 & \\
\hline 3 & $\begin{array}{l}\text { cement - sand - microfibres - water } \\
\text { cement - piasek - mikrowłókna - woda } \\
\left.\text { (ratio/stosunek: } 1: 2: \frac{1}{2}: 2\right)\end{array}$ & 7.5 & \\
\hline 4 & $\begin{array}{l}\text { cement - sand - seeds - microfibres - water } \\
\text { cement - piasek - nasiona - mikrowłókna - woda } \\
\text { (ratio/stosunek: } 2: 1: 1 \frac{1}{2}: \frac{1}{2}: 2 \text { ) }\end{array}$ & 7.00 & \\
\hline 5 & $\begin{array}{l}\text { Cement - sand - seeds - microfibres - water } \\
\text { Cement - piasek - nasiona - mikrowłókna - woda } \\
\text { (ratio/stosunek: } 2: 1: 2: \frac{1}{2}: 3 \text { ) }\end{array}$ & 5.00 & \\
\hline 6 & $\begin{array}{l}\text { Cement - sand - seed - water } \\
\text { Cement - piasek - nasiona - woda } \\
\quad\left(\text { ratio/stosunek: } 1: 2: 3: \frac{3}{4}\right)\end{array}$ & 1.00 & \\
\hline 7 & $\begin{array}{c}\text { lime - seed - sawdust/shavings - hemp litter - water } \\
\text { wapno - nasiona - trociny/wióry - ściółka konopna - woda } \\
\left.\text { (ratio/stosunek: } 2 \frac{1}{2}: 2: 2: 2: 4\right)\end{array}$ & 3.00 & \\
\hline 8 & $\begin{array}{l}\text { cement - sand - sawdust/shavings - water } \\
\text { cement - piasek - trociny/wióry - woda } \\
\text { (ratio/stosunek: } 1: 3: 2: 3)\end{array}$ & 2.00 & \\
\hline
\end{tabular}




\begin{tabular}{|c|c|l|l|}
\hline No./ Nr & Proportion of materials / Proporcje materiałów & Mark / Ocena & Photographs / Zdjęcia \\
\hline 9 & $\begin{array}{c}\text { cement - sand - seed - water } \\
\text { cement - piasek - nasiona - woda } \\
\text { (ratio/stosunek: } 2: 2: 2: 1)\end{array}$ & 2.00 & \\
\hline 10 & $\begin{array}{c}\text { cement - sand - seeds - hemp mulch - microfibres - water } \\
\text { cement - piasek - nasiona - ściółka konopna - mikrowłókna } \\
- \text { - woda } \\
\left.\text { (ratio/stosunek: } 1 \frac{1}{2}: 2: 3: 1: \frac{1}{2}: 3\right)\end{array}$ & 1.00 & \\
\hline
\end{tabular}

The most important step was the creation of the mass, without which it would be impossible to form the Emptyseed. As the aim of the project was to make a block in the most ecological way. In the experiment, the amount of ingredients was reduced to a minimum and only natural, biodegradable materials were applied. In need to find the perfect mass, more than 32 samples of materials, varying in proportions and elements were prepared and examined(Tab.1). The material used in the research were non-processed ingredients which do not have a destructive influence on the environment (such as hemp litter, wood sawdust, lime, etc.). The entire process of choosing the proportions, drying the mold and waiting for the results took approximately two months. The final mix contained of $33.4 \%$ water, $33.4 \%$ cement, $24.4 \%$ sand, $6.2 \%$ bird feed, and $2.6 \%$ polypropylene fiber.

\subsection{Research and results}

The process of creating the new material was carried out on the premises of Gdansk University of Technology in the Laboratory of Digital Technologies and Materials of the Future (Laboratorium Technologii Cyfrowych i Materiałów Przyszłości), under the patronage of Jan Cudzik and Dominik Sędzicki.

By trial and error method the first 11 samples of the mass were obtained (Fig. 4). The final texture prototypes and properties depended on the used materials, their amounts, and the reactions between the components. Unfortunately, the first stage of this research shown that hemp mulch, sawdust/shavings and lime are not proper bonding elements and therefore they were eliminated from the final formula. This led to the creation of 14 additional samples with different textures and proportions, without the ingredients mentioned above (Fig. 5). Sand, water, cement, birdseed, and polypropylene fiber proved to be the best components. The enabled the creation of the perfect mass and to this end, using only these ingredients, 7 more mold prototypes were made. The mass in the next stage was improved and refined to obtain a material with the most suitable properties.

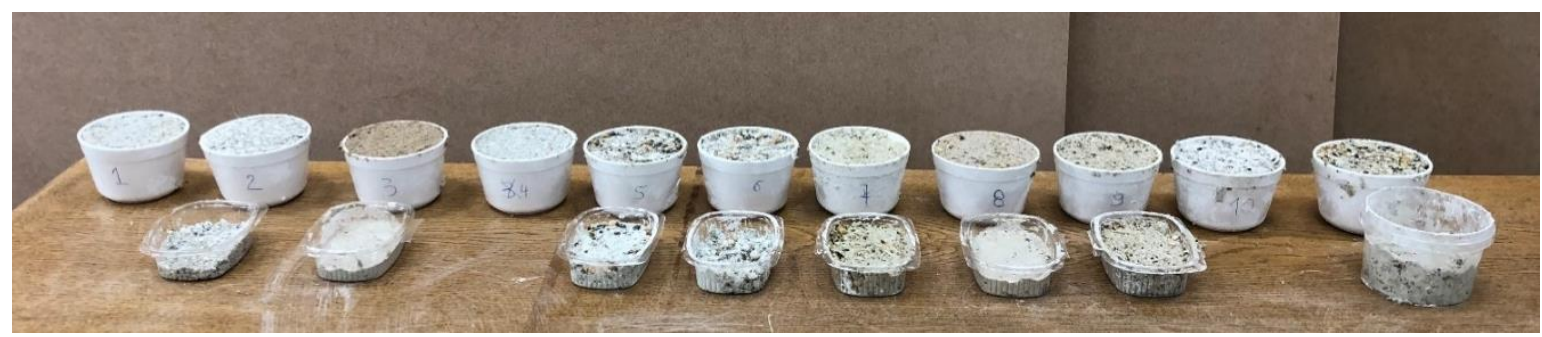

Fig. 4. First material samples. Source: Authors' materials

Rys. 4. Pierwsze próbki materiału. Źródło: Opracowanie własne 


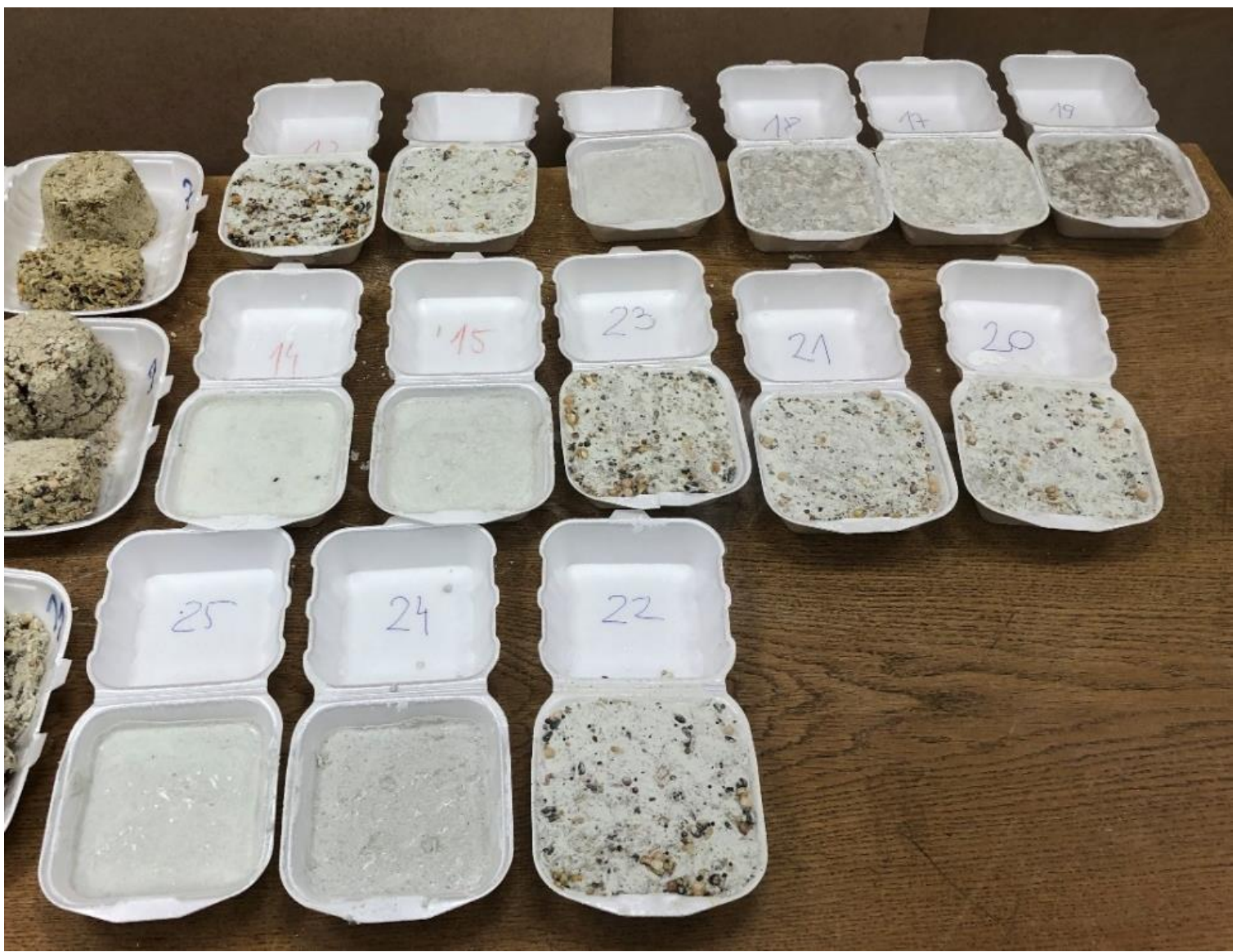

Fig. 5. More samples. Source: Authors' materials

Ryc. 5. Kolejne wykonane próbki. Źródło: Opracowanie własne

All ingredients were carefully selected and analyzed. By mixing the elements in the right proportions, a durable, biodegradable material was created. Its characteristics allow for any shape formation and universal use.

The basic element of the mix is birdseed (e.g. corn, sunflower, sprouts) which acts as the main binder, while cement with water and sand are responsible for the strength of the block. Polypropylene fibers for concrete compact and form a homogeneous mixture, increase its durability and minimize its absorbability.

\subsection{The process of creating Emptyseed block}

Before working on the material, boiling water (about 95 degrees) was poured on the birdseed and set aside for about one hour. The previously prepared dry ingredients (cement and sand) were also poured with water and then mixed thoroughly. The next step was to add the scalded seeds to the mass and to mix the ingredients again by using an electric mixer. Polypropylene fibers and the remaining water were then added to the mixture. The products were mixed until a uniform consistency was obtained. Before pouring the mixture into the mold, the sides of the mold should be buttered or oiled to make it easier to pull the block out later. Finally, the finished mass was poured into a previously prepared mold of waterproof plywood, where for about 3-5 days the material was formed and dried (Fig. 6). After about 72 hours, the hardened model was removed from the mold. In order to do this, it was necessary to disassemble its wooden elements (starting from the sides). The last, middle piece was removed with hammer blows (Fig. 7). Eventually, two prototypes of the Emptyseed block 
were created (Fig. 8). The word Emptyseed was created by mixing two words: empty refers to the hole in the block, and seed is one of the main ingredients of the mass - birdseed.
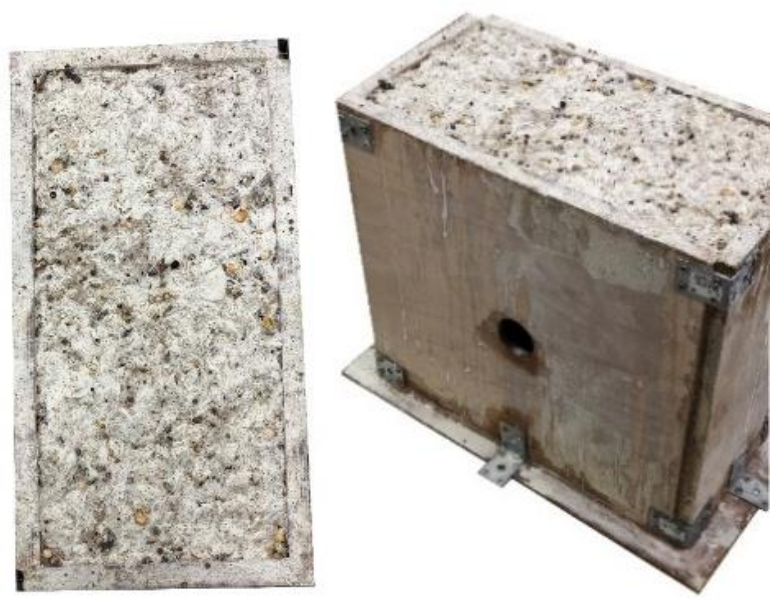

Fig. 6. Ready mass in the mold. Source: Authors' materials Ryc. 6. Gotowa masa w formie. Źródło: Opracowanie własne

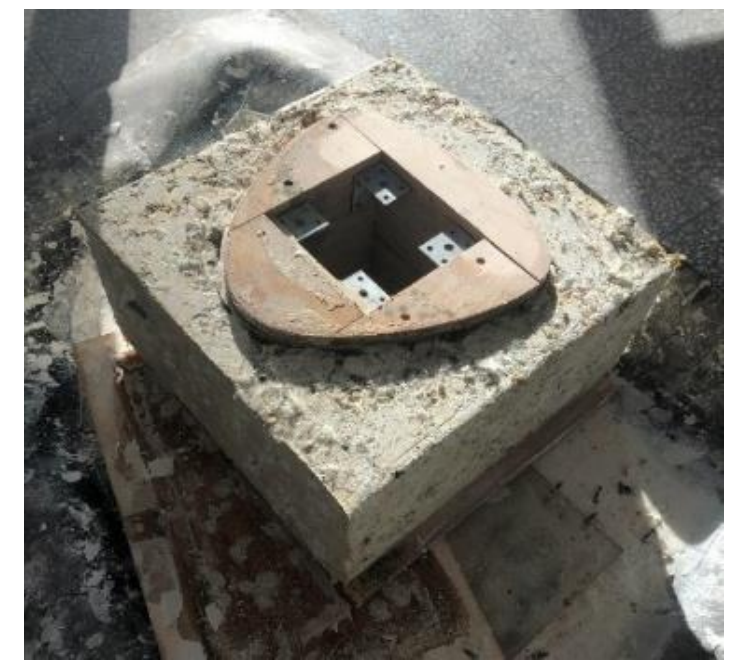

Fig. 7. Process of taking the block out of the mold - the last stage. Source: Authors' materials

Ryc. 7. Proces wyciagania pustaka z formy - ostatni etap. Źródło: Opracowanie własne
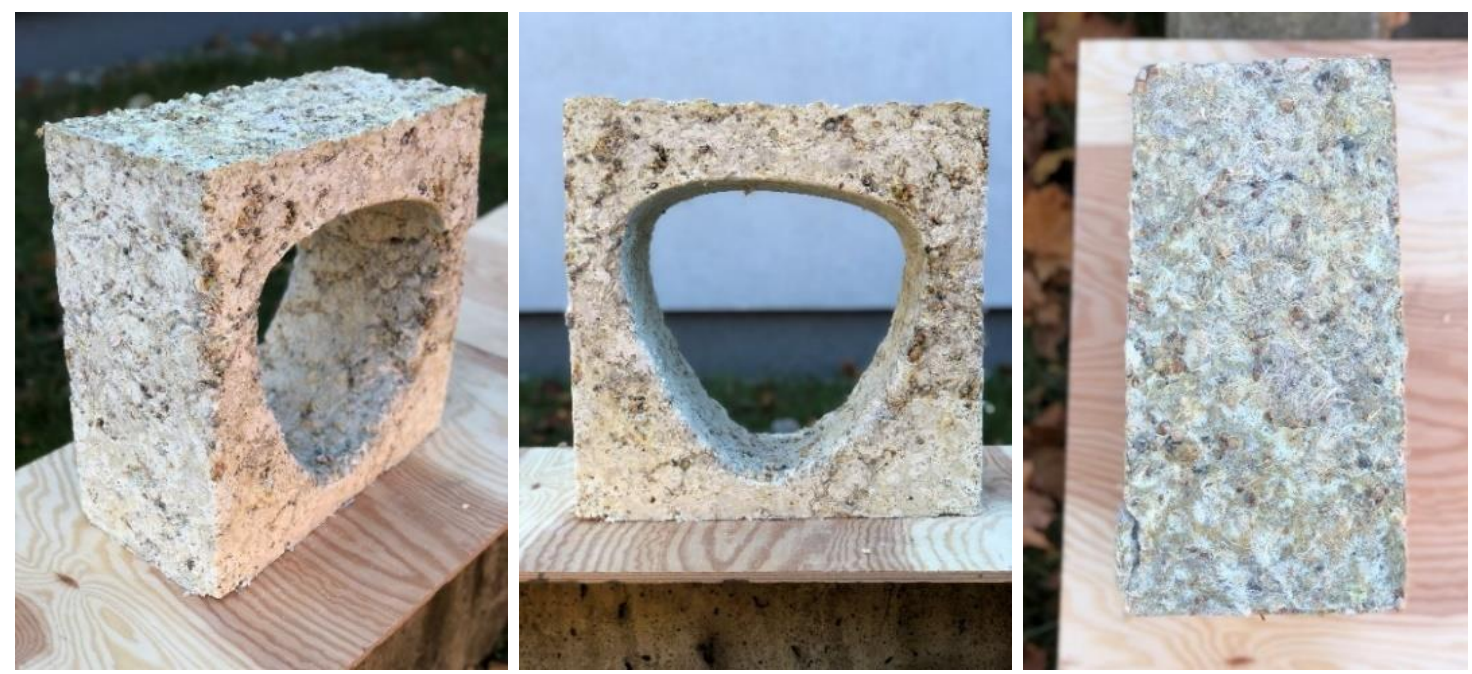

Fig. 8. Emptyseed block - prototype. Source: Authors' materials

Rys. 8. Pustak Emptyseed - prototyp. Źródło: Opracowanie własne

\section{SUMMARY AND CONCLUSIONS}

The action of pro-ecological architecture is not only designing for housing, but the emphasis should be mainly put on sustainability: the materials used, their biodegradability, durability and environmental impact. This effect will not be achieved without continuous work and education of the whole society, but the author believes that with the cooperation of ecologists, entrepreneurs and local people, a balance between the necessary development and the protection of the ecosystem will be found. 
A pro-ecological approach to architectural and socio-economic development will satisfy not only the essential needs of the present generation, but also those of future generations.

It must be remembered that every project should include educational, integrative, visual and functional aspects as it took place with block Emptyseed. This project was not only about finding new material, but also to rise ecological awareness. Emphasis was placed on the use of natural ingredients to find an alternative to mass-produced materials that pollute the environment. The final formula was created out cement, sand, seeds, microfibres and water. The experiment also allowed for the creation of a process diagram for the study of similar solutions in the future. Such and similar solutions as Emptyseed are likely to encourage investors and designers to invest in ecological substitutes and include them in their projects. Thanks to this, these products will gain in popularity, quantity and quality. This will lead to care of ecological safety and implementation the idea of sustainable development in architecture.

\section{TECHNOLOGIA WYTWORZENIA I ZASTOSOWANIA EKOLOGICZNEGO PUSTAKA EMPTYSEED W ARCHITEKTURZE}

\section{WSTĘP}

Obecnie w architekturze nieustannie poszukuje się naturalnych, ekologicznych substytutów dla masowo produkowanych tworzyw sztucznych, które przyczyniają się do zanieczyszczenia środowiska. Temat jest coraz częściej poruszany nie tylko przez biologów i naukowców, ale także przez coraz bardziej świadome społeczeństwo zaniepokojone przyszłością planety. Potrzeba zrównoważonego rozwoju jest współcześnie głównym celem stawianym przed projektantami i architektami, którzy pragną wcielić w życie swoje ideały, a tym samym wpisać swoje projekty w eco-standardy. Z tego też powodu wynika ciągły nacisk nie tylko na walory wizualne obiektów, ale głównie na aspekty środowiskowe i zespolenie $z$ naturą.

Omawiany problem był już badany i analizowany na różnych płaszczyznach. Między innymi Magdalena Zych położyła nacisk na ekologiczne rozwiązania zarówno pod względem formy, funkcji jak i wykorzystania terenu czy użytych materiałów (Zych M., 2020). Podobnie w pracy Kryteria wyrobów materiałów termoizolacyjnych do izolacji obiektów z drewna autorzy skupili się na tym samym zagadnieniu, ale tym razem badania ograniczyły się do dwóch naturalnych tworzyw: wełny drzewnej i wełny szklanej pod kątem właściwości izolacyjnych. Dzięki temu chcieli sprawdzić, jak wpływają zmiany w poziomie zawilgocenia w strukturze budynku (Misztal B., Mielińska A., 2021). Dodatkowo Piotr Wróbel odnosi się do wzajemnego oddziaływania architektury z naturą w dobie zmian klimatycznych. Próbuje oszacować, w jaki sposób zmiany pogody wpływają na struktury zabudowane i proponuje wdrożenie radykalnej koncepcji eliminacji działań niezgodnych $\mathrm{z}$ formułą zielonej architektury (Wróbel P., 2019).

W celu wprowadzenia zrównoważonego rozwoju, w tym prawidłowego nadzoru nad projektowaniem, budową i utrzymaniem budowli, powstała specjalna ustawa o prawie budowlanym (Ustawa 1994). Akt reguluje kwestię związane $z$ ochroną środowiska w trakcie wszystkich etapów budowy, w tym działanie w sytuacji, gdy dojdzie do katastrofy budowlanej czy rozbiórki. Podobnie ustawa o wyrobach budowlanych (Ustawa 2004) porusza zbliżoną tematykę, tym razem skupiając się na samych wspomnianych wyrobach, ich właściwościach oraz stopniu użytkowania. Dodatkowo kontroluje gotowe produkty wprowadzane do obrotu i ich wpływ na otaczającą naturę. Jednak wspomniane regulacje nie są uznawane za akty szczególne, ponieważ nie zawierają wszystkich istotnych norm dla ekologów. 
O ogromnej skali problemu związanego $z$ walką z nadmiarem odpadów i zanieczyszczonym środowiskiem może świadczy fakt, że od kilku ostatnich lat występuje spór o to, czy odrębnie prawo do ekologii należy traktować jako jedno z podstawowych praw i wolności człowieka. Ze względu na wpływ, jaki wywiera potrzeba dostępu do czystszego środowiska, do związanego z tym zdrowia, do naturalnych zamienników dla tworzyw sztucznych, większość stanowią zwolennicy tego poglądu, którzy uważają, że już teraz niezaprzeczalny jest fakt zasadności treści, charakteru, jak i samego sensu omawianego prawa, które, mimo że nie występuje w polskich aktach prawnych, to $z$ wielu norm daje się łatwo wyinterpretować. Co więcej, jest ono na tyle rozległe (dotyczy praktycznie każdego) że powinno być dostępne, powszechne i bezpośrednio egzekwowane, mając podstawę normatywną. Piotr Korzeniowski zwraca uwage na dezintegrację polskich aktów prawnych, których liczne nowelizacje dotyczące prawa ochrony środowiska w sposób niekorzystny wpłynęły na poziom utrzymania bezpieczeństwa ekologicznego. Autor podkreśla, że z pozoru rozbudowany system nie spełnia standardów Unii Europejskiej i posiada odrębne cechy od pozostałych gałęzi prawa, co wiąże się ze wzrastającym chaosem w sferze zadbania o środowisko naturalne (Korzeniowski P., 2012).

\section{METODA}

Obecnie zakres biodegradowalnych materiałów zdaje się być tematem na czasie; architekci prześcigają się w odnajdywaniu coraz ciekawszych i trwalszych form, dzięki którym mogą osiągnąć zbliżone, a nawet takie same efekty jak przy masowych produkcjach. Często za tymi ideami stoją ekologiczne pobudki, takie jak walka z nadmiernymi odpadami, segregacja śmieci, zmniejszenie emisji dwutlenku węgla, oczyszczenie wód czy walka z plastikiem. Ten ostatni zdaje się być plaga XXI wieku i nic dziwnego, że to właśnie dla plastiku szuka się ekologicznych alternatyw, głównie jako materiału budowlanego w architekturze i rzeczach codziennego użytku. Przemysław Brzyski odnosi się do tego problemu zaznaczając, iż budownictwo $w$ XXI wieku jest niestety powodem i generatorem ogromnej ilości odpadów oraz podkreśla, iż dla tworzyw, które sa trudne do utylizowania stale szukane są naturalne zamienniki, głównie te pochodzenia roślinnego (Brzyski P. 2016).

Na popularności zyskuje Hempcrete, czyli cegła z konopi i wapnia. Jest to idealny materiał zarówno izolacyjny, jak i budowlany, ponieważ zawiera celuloze, dzięki czemu w przeciwieństwie do sztucznych włókien chemicznych nie podrażnia ani dróg oddechowych, ani ludzkiej skóry. $Z$ tego mocnego, a zarazem lekkiego materiału inwestorzy budują cale osiedla. Hempcrete jest niezwykle wytrzymały na szkodniki, a co więcej, jest ognioodporny i odnawialny. Barbara Pietruszka i Michał Gołębiewski w rozdziale o kompozytach wapienno-konopnych podkreślają nie tylko walory ekologiczne, ale także termiczno-wilgotnościowe i biologiczne konopi jako materiał budowlany. Dodatkowo, zwracaja uwagę, że wzrost popularności tego surowca w Polsce wymaga czasu ze względu na słabo rozwinięte tereny upraw i potrzebę zaplecza technologicznego (Pietruszka B., Gołębiewski M. 2019). Izolację akustyczną i termiczną oraz masę termiczną betonu konopnego docenili również William Stanwix i Alex Sparrow A. Projektanci opisuja cały proces wykorzystania omawianego naturalnego składnika, a także skupiają się na pozytywnych aspektach jego stosowania. Podkreślają $\mathrm{m}$. in. że przy uprawie konopi nie ma potrzeby używania sztucznych nawozów ani agrochemikaliów (Stanwix W., Sparrow A., 2014).

Bambus jest kolejnym naturalnym budulcem stosowanym przez architektów (głównie w Azji, Afryce i Ameryce Łacińskiej), którzy docenili jego dużą wytrzymałość przy lekkości materiału. Wykorzystywana jest prosta, pusta łodyga, a mączka bambusowa powszechnie zastępuje podstawowe materiały, takie jak drewno czy beton przy budowie drzwi, podłóg i struktury dachów. Właściwości bambusa jako budulca sa uważane za stosunkowo przyjazne dla środowiska oraz posiadają zrównoważony wpływ na jego kształtowanie. Badania przeprowadzone nad cechami omawianego tworzywa wykazały, że pod względem fizycznym oraz mechanicznym bambus wykazuje zwiększoną wytrzymałość w porównaniu do innych podobnych włókien. $Z$ architektonicznego i inżynierskiego punktu widzenia bambus jest on uznawany za materiał o właściwościach zbliżonych do innych naturalnych budulców (Chaowana K., Wisadsatorn S., Chaowana P., 2021). 
Pozytywne aspekty roślin doceniają producenci, jak i smakosze kawy - powstaje coraz więcej inicjatyw, w których wykorzystuje się odpady z fusów po kawie. Wielu autorów twierdzi, że materiały pochodzenia roślinnego są obecnie wykorzystywane do produkcji opakowań i biopaliw (...) odpady z kawy mogą być uważane za cenne źródło w recyklingu dla zrównoważonej produkcji chemikaliów, materiałów i paliwa pochodzenia biologicznego. Co więcej, zauważają, że poszukiwanie zrównoważonych alternatyw dla surowców ropopochodnych staje się coraz bardziej popularne, w szczególności w przypadku pozyskiwania paliwa z biozasobów. Odpady kawy są niedrogim surowcem zawierającym kwasy tłuszczowe, które mogą być wykorzystywane jako substytut dla węgla. Dodatkowo są one także źródłem wielu związków bioaktywnych czy włókna (Sisti L. i inni autorzy, 2021). To rozwiązanie wykorzystała polska firma EcoBean do produkcji brykietu z kawowych fusów, która uważa, że jest to zdecydowanie bardziej ekologiczna wersja w porównaniu z brykietem drzewnym. Produkcja polega na tym, że w pierwszej kolejności fusy są suszone i oczyszczane, a następnie łączy się je z materiałami spalającymi by na ostatnim etapie mogły ulec sprasowaniu. Brykiet z fusów kawy emituje większą ilość energii niż brykiet drzewny. Dzięki temu EcoBean ma nadzieje na zredukowanie emisji CO2 oraz ograniczenie powstałych zanieczyszczeń. Dodatkowo, przedsiębiorstwo ma w planach budowę zeroemisyjnej i zeroodpadowej fabryki, przetwarzającej fusy z kawy.

Biodegradowalne, naturalne składniki są pierwszym krokiem do walki o lepsze jutro i zrównoważony rozwój. W tej bitwie nieodzowne będzie poszerzanie terenów zielonej architektury (green construction), o której pisał Defne Hensel. Autor poruszył tak ważne zagadnienie, jakimi są prototypy ekologiczne, polegające na tworzeniu zintegrowanych i adaptacyjnych systemów zarówno projektowania, jak i budowy i praktyk. Wszystkie one łączą w sobie ekologię, krajobraz, a także architekturę, rolnictwo oraz ogrodnictwo. Stworzony nowoczesny system GC ma za zadanie zrównoważyć cele środowiskowe i potrzeby społeczne, w tym wpłynąć na rewitalizację terenów handlowych. Celem tych działań jest nie tylko świadczenie usług ekosystemowych, ale także ożywienie zdegradowanych peryferyjnych obrzeży miast (Hensel D., 2020).

\section{PROJEKT PUSTAKA EMPTYSEED}

\subsection{Koncepcja}

Główna koncepcja projektu była próba kreacji materiału z surowców odnawialnych w taki sposób, aby stworzyć dzieło przyjazne dla środowiska a zarazem innowacyjne pod względem architektonicznym. Walory estetyczne także odegrały swoją rolę, ponieważ pustaki były dekoracyjnym elementem elewacji budynku (FIG. 1). Pracując nad formą idealną oraz nad właściwościami naturalnych składników, powstał trwały, wytrzymały pustak, który jest w pełni biodegradowalny.

\subsection{Forma}

Proekologiczny pustak Emptyseed posiada prostą, minimalistyczną formę o wymiarach: wys. $40 \mathrm{~cm}$, szer. $40 \mathrm{~cm}$. i gr. $20 \mathrm{~cm}$. Bryła jest oparta na kwadracie $z$ otworem w środku. Otwór nawiązuje do elementów małej architektury we wspomnianym projekcie magisterskim o marinie jachtowej. Nieskomplikowany projekt miał w przyszłości ułatwić pracę nie tylko pracownikom branży budowlanej, ale także umożliwić osobom postronnym wykonanie własnoręcznego pustaka. $Z$ tego powodu do stworzenia Emptyseed nie potrzeba więcej elementów niż w przypadku produktów wykorzystywanych masowo.

Pierwszym krokiem było wprowadzenie danych do programów AutoCad i 3dsMax oraz określenie wymiarów pustaka w taki sposób, aby bryła mogła powstać i nabrać określonego kształtu. Następnie uzyskane informacje zostały wygenerowane do programu Rhino, tak aby przygotować plik do fabrykacji i wycięcia z arkusza wodoodpornej liściastej sklejki o formacie 250x125 cm. W kolejnym etapie poszczególne elementy zostały wycięte ze sklejki o grubości $8 \mathrm{~mm}$ za pomocą frezarki CNC (sterowanej programem komputerowym). Uzyskane elementy musiały zostać wyszlifowane za pomocą szlifierki do drewna oraz papieru ściernego. Ostateczna forma do odlewu pustaka składała się z 49 elementów, które zostały połączone ze sobą za pomocą kątowników oraz wkrętów. 
Najważniejszy krok stanowiło stworzenie masy, bez której niemożliwe byłoby uformowanie pustaka. Jako że celem projektu było wykreowanie bloku w najbardziej ekologiczny sposób, to zredukowano ilość składników do minimum, a także wykorzystała tylko naturalne, biodegradowalne materiały. W potrzebie odnalezienia masy docelowej wykonano 32 próbki materiałów, różniących się między sobą proporcjami i elementami, bazując głównie na składnikach nieprzetworzonych, które nie wywierają destrukcyjnego wpływu na środowisko (m. in. ściółka konopna, trociny drzewne, wapno)(Tab.1). Sam proces dobierania proporcji, wysychania formy i oczekiwania na efekty zajął dwa miesiące. Ostateczna wersja masy zawierała 33,4\% wody, 33,4\% cementu, 24,4\% piasku, 6,2\% karmy dla ptaków oraz 2,6\% włókien polipropylenowych.

\subsection{Przebieg badań i ich wyniki}

Proces powstawania nowego materiału został realizowany na terenie Politechniki Gdańskiej w Laboratorium Technologii Cyfrowych i Materiałów Przyszłości, pod patronatem: Jana Cudzika oraz Dominika Sędzickiego.

Metodą prób i błędów uzyskano pierwsze 11 próbek masy. Ostateczne prototypy tekstur i właściwości były zależne od użytych materiałów, ich ilości oraz reakcji między składnikami. Niestety z uzyskanych badań okazało się, że zarówno ściółka konopna, trociny/wióry oraz wapno nie są dobrymi elementami spajającymi, w związku z czym je wyeliminowano. Postanowiono zrobić kolejne 14 próbek o różnych strukturach i proporcjach, bez wspomnianych wyżej składników. Najlepszymi częściami składowymi okazały się: piasek, woda, cement, nasiona dla ptaków oraz włókna polipropylenowe. To z nich wykonano masę idealna i w tym celu, przy użyciu tylko tych składników, kontynuowano eksperyment w postaci 7 kolejnych prototypów formy. Masa w kolejnym etapie została ulepszana i dopracowywana, tak aby uzyskać materiał o jak najlepszych właściwościach.

Wszystkie składniki zostały starannie dobrane i przeanalizowane. Dzięki wymieszaniu elementów w odpowiednich proporcjach powstał wytrzymały, biodegradowalny materiał, którego cechy charakterystyczne pozwalają na dowolne formowanie kształtu i uniwersalne zastosowanie.

Podstawowym elementem mieszanki są nasiona dla ptaków (m. in. kukurydza, słonecznik, kiełki), które pełnią funkcję głównego spoiwa, zaś cement z wodą i piaskiem odpowiadają za wytrzymałość pustaka. Włókna polipropylenowe do betonu zagęszczają i tworzą jednolitą mieszankę, zwiększają jej trwałość oraz minimalizują nasiąkliwość.

\subsection{Przepis na pustak}

Godzinę przed rozpoczęciem prac nad materiałem nasiona dla ptaków zostały zalane wrzątkiem i odstawione. Przygotowane wcześniej suche składniki (cement i piasek) także zostały zalane wodą, a następnie dokładnie zmieszane ręcznie. Kolejnym etapem było dodanie do masy wyparzonych nasion i ponowne zmieszanie składników za pomocą elektrycznego mieszadła. W dalszej kolejności do mieszanki zostały dorzucone włókna polipropylenowe i pozostała ilość wody. Produkty mieszano do momentu uzyskania jednolitej konsystencji. Przed wlaniem masy do formy należało posmarować jej ścianki masłem lub oliwą, tak aby ułatwić późniejsze wyciąganie pustaka. Finalnie gotowa masa została przelana do przygotowanej wcześniej formy ze sklejki wodoodpornej, gdzie przez około 3-5 dni materiał się formował i schnął. Po około tygodniu oczekiwania utwardzony model został wyjęty z formy. W tym celu było konieczne rozkręcenie poszczególnych jej drewnianych elementów (zaczynając od bocznych). Ostatni, środkowy element został usunięty za pomocą uderzeń młotkiem. Ostatecznie udało się stworzyć dwa prototypy pustaka Emptyseed. Nazwa odnosi się do dwóch słów: empty=pusty oraz seed=nasiono. Słowo empty nawiązuje do otworu w bryle pustaka, a seed do jednego z głównych składników masy, czyli nasion dla ptaków.

\section{PODSUMOWANIE}

Działaniem proekologicznej architektury jest nie tylko projektowanie pod zabudowę mieszkaniową, ale nacisk powinien być położony głównie na zrównoważony rozwój: użyte materiały, ich biodegradowalność, trwałość i wpływ na środowisko. Efekt ten nie zostanie osiągnięty bez nieustannej pracy 
i edukacji całych społeczeństw, ale autorzy wierzą, że przy współpracy ekologów, przedsiębiorców i lokalnej ludności uda się odnaleźć balans pomiędzy niezbędną zabudową a ochroną ekosystemu. Proekologiczne podejście do rozwoju architektonicznego oraz społeczno-gospodarczego pozwoli zaspokoić nie tylko niezbędne potrzeby obecnego pokolenia, ale również przyszłych.

Warto pamiętać, że każdy projekt powinien zawierać elementy edukacyjne, integracyjne i wizualne, jak i aspekty estetyczne i funkcjonalne (tak miało miejsce w przypadku pustaka Emptyseed). W omówionym projekcie celem było nie tylko znalezienie nowego, ekologicznego materiału i stworzenie zupełnie czegoś nowego, ale także zwiększenie świadomości ekologicznej. Nacisk położono na wykorzystanie naturalnych składników, aby znaleźć alternatywę dla materiałów masowej produkcji, które zanieczyszczają środowisko. Ostateczna formuła została stworzona z cementu, piasku, nasion, mikro-włókien i wody. Eksperyment pozwolił również na stworzenie schematu procesu umożliwiającego badanie podobnych rozwiązań w przyszłości. Tym samym wspomniana inicjatywa, jak i podobne rozwiązania do Emptyseed mają szansę zachęcić inwestorów i projektantów do inwestowania w ekologiczne substytuty i umieszczenia ich w swoich projektach. Dzięki temu biodegradowalne produkty zyskają na popularności, ilości i jakości. Umożliwi to zadbanie o bezpieczeństwo ekologiczne i zrealizowanie idei zrównoważonego rozwoju w architekturze.

\section{BIBLIOGRAPHY}

Banach M., Januchta-Szostak A., Architektura wobec wyzwań zrównoważonego rozwoju. Tom 2. Człowiek Ekologia - Architektura, Politechnika Poznańska, ISBN 978-83-7775-438-2

Brzyski P., Budownictwo z wykorzystaniem kompozytu wapienno-konopnego-charakterystyka materiału, Przegląd Budowlany 1/2016, s. 29-33

Chaowana K., Wisadsatorn S. and Chaowana P. Bamboo as a Sustainable Building Material_Culm Characteristics and Properties, Sustainability 2021, 13, 7376, pages 1-18

Frejlich C., Lisik D., Zaprojektowane. Polski dizajn 2000-2013, 2+3D, ISBN 978-83-935975-3-6

Hensel D.S., Ecological Prototypes: Initiating Design Innovation in Green Construction, Sustainability 2020, pages 1-17

Holstov A., Farmer G., Bridgens B., Sustainable Materialisation of Responsive Architecture, Sustainability 2017, 9,435 , pages $1-20$

Korzeniowski P., Bezpieczeństwo ekologiczne jako instytucja prawna ochrony środowiska, Wydawnictwo Uniwersytetu Łódzkiego, Łodź 2012, s. 162

Liu I., Wong J., Eco Design: Furniture, Promopress 2019, ISBN 8417412409

Magwood C., Essential Hempcrete Construction: The Complete Step-By-Step Guide, New Society Publishers 2016, ISBN 9781550926132

Misztal B. Mielińska A. Kryteria wyboru materiałów termoizolacyjnych do izolacji obiektów z drewna, wyd. Przestrzeń i forma 46/2021, s. 88-100

Nawrot C., Mizera J., Kurzydłowski K., Wprowadzenie do technologii materiałów dla projektantów, Oficyna Wydawnicza Politechniki Warszawskiej 2006, ISBN 9788372076397

Pietruszka B. Gołębiewski M., Właściwości wyrobów budowlanych na bazie konopi, Przegląd Budowlany 10/2019, s. 139-141

Sisti L., Annamaria Celli A., Totaro G., Cinelli P., Signori F., Lazzeri A., Bikaki M., Corvini P., Ferri M., Tassoni A., Navarini L., Monomers, Materials and Energy from Coffee By-Products: A Review, Sustainability 2021, pages 1-19

Stanwix W., Sparrow A., The Hempcrete Book: Designing and Building with Hemp-Lime, Green Books 2014, ISBN 9780857841223

Ustawa z dnia 7 lipca 1994 r. Prawo budowlane Dz. U. 1994 Nr 89 poz. 414

Ustawa z dnia 16 kwietnia 2004 r. o wyrobach budowlanych Dz. U. 2004 Nr 92 poz. 881 
Wróbel P. Przekształcenia w relacjach architektury i natury pod wpływem zmian klimatycznych, Przestrzeń i forma $\mathrm{nr}$ 39/2019, s. 144-156

Zych M. Architektura obiektów edukacyjnych posiadających certyfikat ekologiczny, Przestrzeń i forma $\mathrm{nr}$ 43/2020, s. $96-110$

\section{AUTHORS' NOTE}

Jan Cudzik (Architect PhD. Eng.) is a lecturer in the Department of Urban Architecture and Waterscapes at the Faculty of Architecture, Gdańsk University of Technology. Currently conducts research on, among other things kinematic architecture, digital techniques in architectural design, digital fabrication, forms of artificial intelligence in architecture and art.

Konstancja Olszewska (M.Sc. Eng. Arch.) graduate of the Faculty of Architecture at the Gdansk University of Technology. Author of conceptual architectural projects and interior designs using contemporary design methods. Professionally, she runs her own design studio and develops in the field of photorealistic visualizations. Interests: innovative solutions in architecture, graphic design, architectural visualizations, interior design.

\section{O AUTORACH}

Jan Cudzik (dr inż. arch.) adiunkt w Katedrze Architektury Miasta i Przestrzeni Nadwodnych oraz kierownik Pracowni Cyfrowej Fabrykacji na Politechnice Gdańskiej. Obecnie prowadzi badania naukowe dotyczące między innymi architektury kinematycznej, cyfrowych technik wspomagających projektowanie architektoniczne, cyfrowej fabrykacji, form sztucznej inteligencji w architekturze i sztuce.

Konstancja Olszewska (mgr inż. arch.) absolwentka Wydziału Architektury Politechniki Gdańskiej. Autorka koncepcyjnych projektów architektonicznych i projektów wnętrz przy użyciu współczesnych metod projektowania. Zawodowo prowadzi autorską pracownię projektową i rozwija się w dziedzinie fotorealistycznych wizualizacji. Zainteresowania: innowacyjne rozwiązania w architekturze, grafika użytkowa, wizualizacje architektoniczne, projektowanie wnętrz.

Contact | Kontakt: jan.cudzik@pg.edu.pl; konstancjaolszewska@gmail.com 